POSPÍŠIL, I. (ed.) (2018): Leskov i vokrug: konteksty tvorčestva i sostojanije sovremennogo leskovovedenija. Brno.

Revue des études slaves, tome LXXXI, 2010, fascicule 1, Tolstoï 1910. Échos. Résonances. Interprétations.

https://doi.org/10.5817/NR2019-1-9

\title{
Analýza Petra Bicilliho a jeho bulharského působení
}

PETKOVA, G.: Da se dada rokovodešta niška... Istorija na ruskata literatura ot prof. P. Bicili v tri knigi (Bolgarija, 1931-1934). Sofija: Izdatelstvo „Fakel“, 2017.

Docela nedávno vyšel péčí Siedlcké univerzity a agilního Romana Mnicha sborník O Petrovi Bicillim [MNICH 2017], který jsem recenzoval v čas. Opera Slavica [POSPÍŠIL 2018]. Petr Michailovič Bicilli (1879-1953) byl ruský obecný historik, historik kultury, kulturní antropolog, literární vědec a filozof, profesor Novorossijské univerzity v Oděse a Sofijské univerzity. Jeho životní dráha se křižila s drahou budoucího brněnského smluvního profesora Sergije Vilinského (1876-1950).

Galina Petkova/Petkovová ze Sofijské univerzity Klimenta Ochridského přispěla do tohoto sborníku podstatnou, rozhodující měrou, zejména materiálově. V první studii mapuje Bicilliho kurzy na Sofijské univerzitě s využitím dosud publikovaných materiálů. Ukazuje, jak byla Bicilliho pozice v Bulharsku složitá; oproti tomu je život ruské emigrace v meziválečné ČSR - nehledě na všechny potíže a předsudky - takřka idylický. Když se podíváme na kurzy, které Bicilli v Sofii vedl, žasneme nad jejich počtem a rozpětím, ale to je typické pro všechny velké badatele, hlavně tematická rozrůzněnost, ale současně propojenost a komplementarita. To jsme ostatně popsali v recenzi, na niž jsme výše odkázali (např. Dějiny reformace, Dějiny ruské kultury 19. století, Církev a společnost v západní Evropě v době náboženských válek, dokonce historie USA aj.). Galina Petkova/Petkovová se v další studii ještě vrací k „setkáni“ Janka Janeva (1900-1945; bulharský filozof, básník a esejista, absolvent německých univerzit, od roku 1934 přednášel v Berlíně, zahynul při ničivém náletu Spojenců na Dráždany v únoru 1945) a Petra Bicilliho: jde o recenzi na Bicilliho do bulharštiny přeloženou knihu Úvod do nové a nejnovější historie.

V této bulharsky psané knize (název „At̉ se dá vůdčí nit“ souvisí s Bicilliho koncepcí dějin ruské literatury i chrestomatie) se Petkovová zabývá Bicillim (bulharsky se píše s jedním „1") opravdu souborně a hluboce, materiálově důkladně. Ctižádostí autorky bylo současně „osmyslit“ problém emigrace, zejména kulturní a vědecké, a zjistit, kterak se promítala do práce a využití jejích výsledků. Analyzovaná doba 
1931-1934 pokrývá podstatné Bicilliho publikační výstupy, a to Chrestomatii z dějin ruské literatury a druhou část Stručných dějin ruské literatury. I když byly tyto knihy kladně hodnoceny jak Bulhary, tak Rusy v emigraci, byly postupně vytlačovány, jak autorka uvádí, na okraj ruské emigrantské produkce a dokonce i na periferii samotného Bicilliho. Svůj postup, jenž uplatňuje, jde údajně ve stopách Bicilliho analytismu (nebot’ tento literární vědec, kulturolog a historik byl zjevně spíše analytikem než syntetikem), je, jak tomu autorka ř́ká, „emigrantská archeologie“, tj. mikroanalýza detailů.

První část publikace shrnuje to, co už známe z ruskojazyčného siedlckého sborníku, tedy podrobnou analýzu Bicilliho působení na Sofijské univerzitě, včetně různých překážek a ústrků administrativního rázu, mezi počátkem a koncem jeho působení (1924-1948). Tematické rozpětí jeho přednášek bylo už zmíněno v Opera Slavica a zčásti i zde. Měl tu arcit konkurenta prof. Michaila Popruženka (1866-1944), který zde pracoval už od roku 1920 jako přednášející „historie bulharské a slovanských literatur“. Oba profesoři byli absolventy oděské Novorossijské univerzity a byli primárně reprezentanty ruské medievistiky, stejně jako „náś" Sergij Vilinskij - byla to asi konkurence dost úporná, nebot oba se svými projekty (tak se tyto programy nebo plány opravdu nazývaly - byl to zjevně vliv tehdy módního amerického pragmatismu) chtěli působit na bulharské autority. Autorka sleduje i Bicilliho styky, mj. s Bojanem Penevem (1882-1927). Oba byli ctiteli Ivana Bunina. Zmiňuje se i tzv. sofijský gogolovský sborník z 30. let minulého věku, v němž participovali mj. A. Bem, V.Zeňkovskij a S. Gessen (Hessen) aj. Ve výuce byl Bicilli nicméně vytlačován do sféry historie a kulturní historie. Bulharský stát věnoval z počátku 20. let i později dost financí na podporu ruské badatelské školy v Bulharsku. A v tomto ohledu se Bicilli zabýval i koncepcemi vzdělávání Rusů na univerzitách a hlavně na středních školách mimo Rusko. Nezanedbatelná je jeho činnost recenzentská, v níž se zabývá ruskými publikacemi: Je v tom je důkladně racionální, pragmatický, svým způsobem přísný. Knihu o ruských dějinách sice nenapsal, ale zato vytvořil zmíněnou chrestomatii z ruské literatury a podílí se i na revizi předrevoluční výuky historie a literatury. Autorka pečlivě studuje genezi publikací, jejich zdroje, recepci a šíření. Bylo by jistě užitečné srovnat Bicilliho koncepce dějin ruské literatury s tím, co vytvořil např́klad v českém prostoru Jevgenij (Evžen) Ljackij (1868-1942), Bělorus píšící hlavně rusky, také básník a prozaik. Obě Bicilliho publikace autorka pokládá za komplementární a vysoce inspirativní. Autorka považuje chrestomatii i obě části stručné historie ruské literatury za osobitou kompenzaci toho, co Bicilli vlastně v Sofii v podstatě nemohl přednášet, ale takto se $\mathrm{k}$ ní vyjádřil a pro studenty to bylo nebo mohlo být klíčové (littera scripta manet); kromě toho je tu zjevný i kánon přednášek a zvláštní funkce paměti, nebot pro Rusko je, jak píše, pamět literárněcentrická. Bohužel všechny tyto publikace vznikající na vrcholu Bicilliho bulharského působení, nebyly ruskou emigrací př́liš využívány, stály pořád na okraji, možná i pro excentričnost 
bulharské monarchie vzhledem k západní a koneckonců i střední Evropě (Francie, Československo, do jisté doby i ruský Berlín).

Podle mého soudu je tato „archeologie“ nezbytná k pochopení vývoje ruského literárněvědného myšlení i pro evoluci emigrace jako takové. Problematičtější je totiž to, zda by mělo zůstat u tohoto „retra“ nebo by se bylo možné Bicillim i dnes alespoň inspirovat. Editor citovaného siedlckého sborníku Roman Mnich upozornil, že tvorba Bicilliho obsahuje podněty, které vyzývají k široké diskusi. Podle Mnicha se do Bicilliho promítají úvahy o proslulých křižovatkách ruské literatury, někdy se však dílo Bicilliho př́liš aktualizuje a modernizuje, např́klad se chápe jako předchůdce sémiotiky, i když lze připustit, že takové podněty $\mathrm{v}$ jeho díle najdeme. Mnich chce upozornit na ty impulsy Bicilliho, které zůstaly stranou dobové pozornosti, tedy na věci jen zdánlivě marginální, periferní. To jsou zejména jeho recenze, v nichž komentuje dílo ruských klasisků a literárních vědců, mimo jiné na knihu Ivana Bunina Osvobození Tolstého nebo na monografii A. Bema o Dostojevském nebo na Šklovského Заметки о прозе Пушкина z roku 1938. Bicilli není teoretik, ale ani historik literatury: je to analytik ve zkoumání detailů, nebot v nich je skryto jádro literárního poselství - to je však třeba u Bicilliho objevit, někdy dokonce jen „mezi řádky“.

Studie bulharské rusistky přináší zajímavý materiál a jeho analýzu. Jde jen o to, aby působila i koncepčně, inspirativně. Její potencialita $\mathrm{k}$ tomu směřuje.

Ivo Pospíšil

\section{Bibliografie:}

MNICH, R. (ed.) (2017): Petr Bicilli: dialog na perekrestke kul'tur. Monografija pod redakciej Romana Mnicha. Opuscula Slavica Sedlcensia, tom XIV. Siedlce.

PETKOVA, G. (2017): Da se dada rokovodešta niška... Istorija na ruskata literatura ot prof. P. Bicili v tri knigi (Bolgarija, 1931-1934). Sofija.

POSPÍŠIL, I. (2018): Podněty díla Petra Bicilliho (Petr Bicilli: dialog na perekrestke kul'tur. Monografija pod redakcijej Romana Mnicha. Opuscula Slavica Sedlcensia, tom XIV. Instytut Kultury Regionalnej i Badań Literackich im. Franciszka Karpińskiego, Siedlce 2017. ISBN 978-83-64884-81-8). Opera Slavica 2018, XXVIII, č. 1, s. 71-76. 